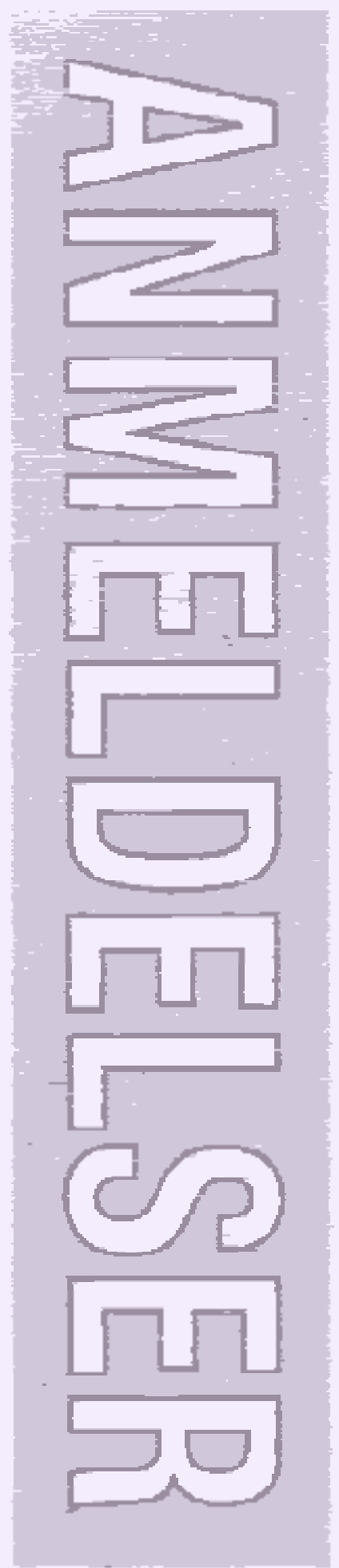

Lars-Henrik

Schmidt:

Diagnosis 1.

Filosoferende eksperimenter.

Kobenhavn:

Danmarks Pædagogiske Institut (DPI) 1999 (302 s.)

Rektor for det nydannede pædagogiske universitet, Lars-Henrik Schmidt (L-HS), nåede netop at barsle med et 3 binds værk inden udgangen af det forrige årtusinde: Diagnosis I, II og III. Bind I (med undertitlen "Filosoferende eksperimenter"), som denne anmeldelse forholder sig til, præsenteres i forordet som et bud på en tragisk filosofi, en fundering, hvor bd. II og III ("Socialanalytiske fatninger" og "Pædagogiske forhold") karakteriseres som praktiske og teoretiske omsætninger og investeringer. Strukturen giver nogle gentagelser mellem de tre bind, men gør det også muligt kun at læse dele af teksten særligt i bd. II og III, som bærer præg af at være sammenføjede lejlighedstekster.

L-HS producerer en ganske original type meningsdannelse, det er hverken kustodens idéhistorie eller videnskabsmandens repræsentationer. Analyserne skal ikke repræsentere nutiden, men alligevel vil de noget ift. nutiden, de vil træffe, tage tegn, tilbyde en sammenhæng. Men sådanne træfninger og tegntagninger sker ikke forudsætningsløst - forudsætningerne præsenteres i Diagnosis I, hvor det er hen- sigten at udvikle et kategorialt netværk, som skal gøre det muligt at navigere mindre usikkert. L-HS' yndede figur er da også kortet, som giver retning uden - som modellen - at postulere at repræsentere. Som L-HS siger i forordet er hans filosofi ikke rigtig eller forkert, ikke korrekt eller ukorrekt, men anvendelig eller ej. Ambitionen er at lægge et mønster frem, der træffer tidens erfaring.

De egensindige vinkler til trods følger kapitelopdelingen i Diagnosis I velkendte filosofiske problematikker: erkendelsesteori (kap. 1), filosofisk antropologi (kap. 2), æstetik (kap. 3), etik (kap. 4) og politisk filosofi (tillæg). Erkendelses-ambitionen, som den formuleres i kapitel 1 er ikke at skabe ny viden, men at artikulere det selvfølgelige. Ikke det ligegyldigt selvfølgelige, men dét selvfølgelige, der skaber historie. Målet med en sådan artikulation er at fortælle en anderledes historie Det selvfølgelige knyttes til begrebet om gemenhed, som bestemmes som det, der endnu ikke er uenighed om, det hvis artikulation ikke forarger, det sociale. Den socialanalytiske ambition bliver at følge artikulationer af det sociale - det sker gennem idéhistoriske analyser og det sker gennem samtidsdiagnoser, hvor Schmidt søger at træffe de aktuelle selvfølgeligheders artikulation. Her er inspirationen fra ikke mindst Nietzsche og Foucault eksplicit.

Socialanalytikken spørger til, hvordan der rent faktisk produceres viden. Det hand- 
ler om at bestemme de tendenser i samtidens tænkning, der vil vise sig at bære historie. I kapitel 1 formuleres denne forskningsstrategi, og der udpeges nogle tommelfingerregler eller en analysestrategi for en praktisk-poetisk filosofi. Det centrale spørgeord for denne analysestrategi er "hvordan", det handler om at spørge, hvordan et "at" gennem artikulationen bliver et "hvad". Analysegenstanden er gjorte kendsgerninger, og analysen undersøger, hvordan noget er blevet gjort til sådanne kendsgerninger.

Samtidig er det dog karakteristisk, at L-HS i sine filosofiske spekulationer overskrider sin egen spørgehorisont og selv går i front med artikulationer af det gemene, selv "gør kendsgerninger". Det gælder fx i kapitel 2, hvor han søger at formulere nogle "socialer" (og ikke eksistentialer som hos Heidegger), dvs. nogle ærkeerfaringer, som karakteriserer vores sociale vilkår. Han når frem til tre sådanne socialer nemlig hjemløshed (du er ikke alt, identiteten er mangelfuld), afmagt (du skal dø) og en suverænitetsfordring (det analyseres hvordan den er blevet artikuleret gennem de sidste 50 år: at vælge sig selv, at finde sig selv, at gøre sig til, at skabe sig selv osv.). Ud fra disse erfaringer søger L-HS at udvikle rummets og tidens kategori.

Ifølge Schmidt handler dannelse om smagens dannelse, altså om æstetisk dannelse. Han advokerer i kapitel 3 for en utraditionel dan- nelse. L-HS prøver at udvikle et dannelsesbegreb, der på en gang overtager dannelsens problematik og så tænker den på ny. L-HS bruger dannelseskategorien som spejl for en analyse af forholdet mellem individualitet og socialitet. Nærmere betegnet handler dannelse om individets overskridelse i/til det sociale. Dannelsen sker gennem (eller er?) denne overskridelse. Det handler for nu at give et enkelt eksempel på Schmidts begrebsbrug om en "individualitetsforsikrende individualitetsoverskridelse og en individualitetsoverskridende individualitetsforsikring".

Dannelse knyttes via smagen med humaniora og dens interpretationer, hvor interpretationer handler om adgangen til verden og dermed også til den anden. Moderne dannelse er selvdannelse i form af interpretationer, som samtidig er porten til den anden. Dermed forsøger Schmidt at tænke dannelsen løsrevet fra en traditionsbaseret dannethed, som udelukkende handler om at viderelevere kulturelt arvegods.

Som ved dannelsesbegrebet søger Schmidt at overskride den aktuelle etik-horisont gennem et socialanalytisk blik på etikkens felt og dens idé- og samtidshistoriske artikuleringer. En bunke distinktioner fører frem til formuleringen af en fortrydelses- og syndsetik. Etikken må tænkes ud fra selvforholdet, og det kategoriske imperativ kommer til at lyde “Handl således, at du kan ville gentage den handling". Fortrydelsen er forbrydelsen. I forhold til den anden handler det om erfaringen af at tilhøre dennes forskel. Det handler om at lytte efter protesten og dermed tilkende den anden værdighed. Synd handler om, at respekten for den andens værdighed brydes.

I et tillæg om socialaftalen skitserer L-HS sin politiske filosofi. Det politiske knyttes til konfliktualitet (som så kan artikuleres i freds- eller krigs-termer), der igen knyttes til gemenheden. Gennem læsninger af Machiavelli, Rousseau og Marx når Schmidt fremtil formuleringen af 3 styringsrationaler eller reguleringsformer (loven, kontrakten og institutionen(markedet)), hvor tidsdiagnosen går på, at disse tre instanser i dag fastlægges ved forhandling, hvorved vi har et aftalesamfund. Aftalerne er situationelle magtbalancer, ikke magtfordelinger. I aftalesamfundet gælder den sociale improvisation, hvor reglerne opfindes undervejs til forskel fra lovens imperativ.

Der er bogen igennem en spænding mellem analysestrategierne, der sætter "hvordan" i centrum, og så viljen til at fundere en etik, et dannelsesbegreb $\mathrm{mm}$. Shmidt vil både analysere, hvorledes gemenhed artikuleres og så formulere sine egne bud på, hvordan en etik, en dannelse kan se ud i dag. Disse bud skal dog formodentlig snarere ses som tilbud end som påbud. Der er noget basalt generøst i diagnosens mange 
ideer og samtids/idéhistoriske analyser, som ovenstående beskrivelse har været nødt til at se bort fra.

Hvad enten man køber LHS' grundliggende figurer eller ej, er Diagnosis I oplagt inciterende og inspirerende for arbejdet med en bred vifte af filsofisk-sociologiskpædagogiske problemstillinger. Det er ikke mindst i de analytiske detaljer, i koblingerne, i sammenstillingerne, i de konkrete mønsterdannelser at bogen virker så inspirerende. At der så er nogle af koblingerne, man står uforstående overfor (det gælder ikke mindst nogle af L-HS' kort: Hvorfor lige disse bestemmelser mellem disse koordinater?) tager man med i købet.

Hvem ellers i Danmark evner på en gang at give en omfattende fremstilling af en original filosofi og samtidig vise, hvorledes den kan omsættes i konkrete analyser? Ambitionsniveauet er skyhøjt og indløsningsforsøgene ofte træffende.

Med L-HS har DPU fået en rektor, der vil noget med viden og ikke blot med organisationen. Hvordan den nye pædagogiske filosofrektor vil søge at omsætte og institutionalisere sin socialanalytik, vil den nærmeste fremtid vise. I hvert fald ligger hans videnspolitiske kort nu frit fremme på bordet. Det er bare at gå i gang.

\section{Morten Knudsen}

Institut for ledelse, politik og filosofi, Handelshøjskolen i København
Lars-Henrik Schmidt: Diagnosis II. Socialanalytiske fatninger. Kobenhavn: DPI 1999 (310 s.)

"Når jeg hører nogen sige "spændende", griber jeg hammeren", skriver LarsHenrik Schmidt i slutningen af andet bind i Diagnosis-trilogien. Han udtaler sig ikke som anmeldelsesredaktør, men som kritiker af aktuelle forhold på universiteterne. Forhold, der udmønter sig i, at de universitetsstuderende kalder sig skoleelever og synes, at alt er spændende, især hvis det også er "interessant". At alt fra Kant til Nietzsche er "spændende" tager L-HS som udtryk for en ydre lærdomstilegnelse, hvor engagementet nok er der, men ikke er forbundet med eksistentiel alvor.

Læsningen af bind II er ligesom læsningen af de to øvrige bind ikke et "spændende", men må man sige herligt déjàvu. Schmidts samlede og omfattende produktion genkaldes i de 17 illustrationer af "den analytiske effektivitet", som $i$ andet bind udfoldes på baggrund af første binds analyseafsæt. De Socialanalytiske fatninger er måske i endnu højere grad end de to øvrige binds temaer relevant for sociologer $i$ sine problematiseringer af det sociale.

Det sociale karakteriseres som "den konfliktuelle gemenhed og den gemene konfliktualitet". I og med denne karakteristik vil L-HS gerne manifestere sig som praktiker. Han vil gribe det partikulære i dets historiskhed - diagnosticere, hvad der gør sig gældende i konfliktualiteter, og ikke som en 'traditionel' filosof udlede og kategorisere gyldigheder i det universelle. I en praksis som socialanalytiker gælder det om at lede efter det sociale i dets artikulationsproces - inden det er manifesteret som kultur. L-HS vil endelig ikke være kulturanalytiker, da en sådan ikke fokuserer på denne proces, men blot på kendsgerningerne, hvilket vil sige det sociales artikulerethed som kultur. Det er ikke eksempelvis vittigheden som sådan, der er socialanalytikerens genstand, men den installation af orden, der gør vittigheden morsom på den ene eller den anden måde, eller ikke morsom - har jeg forstået kompleksiteten ret. Således er det ligeså væsentligt som socialanalytiker at være opmærksom på det, der er uden for en orden: Hvilke forhold ligger til grund for, at vi ikke forstår en vittighed.

Karakteristikken af Nietzsches filosofi som en pointernes filosofi og ikke en argumenternes filosofi (s. 46) gælder ligeledes L-HS' socialanalytik. Men trods en gennemgribende inspiration fra Nietzsche holder L-HS ikke som Nietzsche kroppen som ledetråd. En væsentlig ledetråd i L-HS's socialanalytiske fatninger synes snarere at være forskellige dagligsprogsvendinger og ordsprogslignende formuleringer, hvis pointer udfoldes til det geniale. Kapitel 8 om "Grænseløshedens tyranni - 
om et tragisk dilemma" indledes eksempelvis med "Der må være en kant", hvilket bliver en ledetråd for en diskussion af lægefaglighedens grænser. Det socialanalytiske blik på 'det lægelige dilemma' er i øvrigt en af de bedste illustrationer af socius form af det, L-HS gennemgående betegner som gemenhed. Gemenheden defineres som "den endnu ikke erfarede uforligelighed mellem instanser", hvilket i det lægelige dilemma er dilemmaet mellem den lægefaglige erfaring og den almentmenneskelige erfaring og udspiller sig mellem den lægelige profession og den lægelige person. Det sociale fornægtes, når den lægefaglige erfaring, der bygger på kontrollerede videnskabelige resultater, så at sige slås sammen med det menneskelige aspekt i lægens afgørelse. Når man i videnskabens navn vil afskaffe det menneskelige, suspendere det sociale, får termen 'det lægelige dilemma' sin relevans. L-HS fastholder her og også i det efterfølgende kapitel om sundhedsfremme som en ny tids moralfilosofi, at selv kroppen - "lægekunstens klippe - ikke har klippefaste grænser" (s. 174). Lægevidenskaben må leve med det sociale som et vilkår og være henvist til dømmekraften.

L-HS griber, eller snarere kaster alt fra EU til fosteromsorg og kannibalisme ud til kvalificeret debat. Men de mest gribende afsnit - de, der smitter læseren med sin eksistentielle alvor, er de afsnit, der eksplicit bygger på Nietzsche. Schopenhauer fremstilles med sin systematiske tænkning som Nietzsches modsætning, og i LHS's karakteristik af Nietzsche som én, der bruger mange og voldsomme fagter, skimter læseren af Diagnosis forfatterens selvkarakteristik.

Med Diagnosis, om de så fylder tre bind og næsten 1000 sider, er det svært at udlede en systematisk tænkning. En egensindig form for Foucault- og Nietzsche-inspireret perspektivisme, der også favner Kant og Kierkegaard, formår at kaste sit skæve lys på alskens aktuelle fænomener og politikker. Vel at mærke på en sådan måde, at man - ikke nødvendigvis midt i lyskeglen, men også i strålernes diffuse skær - får lyst til at fortsætte udforskningen og debatten, hvor LHS desværre i sin diagnosticering og altomfavnende alvor må slippe den.

Inge Kryger Pedersen, Sociologisk Institut, Københavns Universitet

\section{Lars-Henrik \\ Schmidt: \\ Diagnosis III. Prdagogiske for- hold. Kobenhavn: DPI 1999 (322 s.)}

Idéhistorikeren Lars-Henrik Schmidt har i nogle år huseret som en gavflab i den pædagogiske verden med sine dristige tendensanalyser, først som direktør for Danmarks Pædagogisk Institut og nu som rektor for det nye Danmarks Pædagogiske
Universitet. Alene i kraft af disse topposter knytter der sig mere end almindelig interesse til hans bind III af Diagnosis vedrørende „Pædagogiske forhold“. Schmidt vil heri forsøge at vise, hvorledes hans speciale - det socialanalytiske perspektiv - kan være effektivt som problematiseringsform for pædagogiske forhold.

Interessen for værket skærpes ved, at Schmidt i det indledende tekststykke om pædagogisk forskning lægger op til en moderne videnskabspraksis, der med udgangspunkt i psykologi og sociologi samt antropologi og filosofi minder noget om kultursociologi. Ydermere opererer Schmidt med et nymodens skel mellem traditionel og relevant forskning såvel som med en tese om udviklingen af en ny pædagogik, som han ikke tøver med at benævne den libertinære pædagogik.

Den libertinære pædagogik er (endnu) en ny pædagogik, der godt nok ligner både den frigjorte og den frigørende pædagogik, men som i sit modsætningsforhold til den autoritære pædagogik alligevel er helt anderledes ved at være bundet til opkomsten af, hvad Schmidt betegner som "det moderne personskab", hvor det "så afgjort (er) den indsatte og ikke den ansatte, der spiller første violin. Betydningen af denne forskydning i det pædagogiske forhold kan dårligt overvurderes", konstaterer Schmidt lapidarisk s. 22.

Når forskydningen dårligt kan overvurderes, hænger det sammen med, at den 
ifølge Schmidt er udslag af moderniseringstvang o $g$ indvidualiseringstvang, altså processer man ikke kan unddrage sig. Eller udtrykt med andre ord: Livslang kompetenceudvikling gennem læring er ikke til at komme udenom i det moderne velfærdssamfund på vej ind $\mathrm{i}$ "selvdannelsens epoke". Skal læringen imidlertid undgå at blive en simpel forfaldsform for selvdannelsen, må den ifølge Schmidt lokaliseres inden for rammen af en dannelse til myndighed i regi af de pædagogiske institutioner, der skal være deres sociale ansvar bevidst som dannelsesanstalter.

Gang på gang går han ud fra eller fastslår, at dannelse kan noget, som vi har brug for, når vi udfordres af den libertinære pædagogik. Dannelse kan nemlig både befordre og problematisere den individualitetsoverskridende individualitetsforsikring (se hertil Diagnosis I, kap. 3), så vi bliver mere almenmenneskelige og mindre afmægtige. Det er noget af en påstand og et løfte, men det er ikke desto mindre, hvad Schmidt forstår ved „det store menneskedannelsesprojekt". Projektet skal foruden at tjene myndiggørelsen imødegå snæversyn såvel på det personlige som på det faglige plan, så meget desto mere som samtiden ikke længere er til at forberede børn og unge på noget bestemt. $\mathrm{Nu}$, hvor selv spædbørn fremstilles som kompetente medborgere, er forskydningen fra den politiske til den pædagogiske myndighed klar nok, og vi kan derfor næsten kun som i spejderbevægelsen tale om "at være beredt" eller som Schmidt gøre myndighedens dannelse gældende som det institutionelle hovedanliggende.

Bindet indeholder 21 tekststykker om de pædagogiske forhold inden for de praktiske metierer, som henholdsvis lærere og pædagoger specielt bedriver, og de dermed sammenhængende forsknings- og skolepolitiske forhold. Ikke alle tekststykker er lige træfsikre. Mange af dem er alt for præget af først at have tjent som forelæg ved diverse pædagogiske forsamlingsmøder, og de mange gentagelser og selvreferencer trætter i det lange løb. Teknisk og kunstnerisk efterlader publikationen derfor et dybt uprofessionelt indtryk, hvilket er meget ærgerligt, fordi bindet både som en slags forskningsprogramskitse og som pædagogisk budbringer så absolut fortjener stor opmærksomhed. Schmidts utraditionelle omgang med klassikere som Rousseau, Kant og Nietzsche er ikke hverdagskost i dansk pædagogisk forskning. Desuden udviser han - omend mest indirekte - et omfattende kendskab til aktuelle temaer og spørgsmål på det pædagogiske felt, som han så beriger med sit kraft- og saftfulde socialanalytiske perspektiv. Endelig er han tilpas fræk i kæften til, at det er svært at forblive uberørt af tekstlæsningen, hvad enten man nu bifalder eller fortørnes over hans skarpe indsigter. En mere inciterende publikation end "Pædagogiske forhold" skal man derfor lede længe efter på feltet.

\section{Ejgil Jespersen}

Jydsk Pædagog-Seminarium

\section{Kurt Aagaard Niel- sen, Anni Greve, Finn Hansson, Klaus Rasborg (red): Politik og miljø i det moderne samfund - en antologi om en aktuel kontrovers. Kobenhavn: Forlaget Sociologi,}

Risikobegrebet har stået højt på dagsordenen i europæisk sociologi, siden Ulrik Beck i 1986 udgav Risikogesellshaft. Auf dem Weg in eine andere Moderne (dansk udgave Hans Reitzel 1997). Arbejdet på at undersøge begrebets kritiske potentiale og sociologiske relevans fik for alvor ben at gå på, da den samfundsvidenskabelige trekant Anthony Giddens, Ulrich Beck og Niklas Luhman åbnede 90'erne med markante indlæg i modernitetsdiskursen med udgangspunkt i risikobegrebet ( Beck: Politik in der risikogesellschaft. Essays und Analysen 1991, Giddens: The Consequences of Modernity 1990 og Luhmann: Soziologie des Risikos 1991)

Værkerne oplevedes som en fornyelse i forhold til den ortodokse sociologis paradigmer af flere grunde. Becks teser om de formelle politiske strukturers tilta- 
gende afmagt og de politiske subsystemers tiltagende betydning under globaliseringsprocessen vakte interesse - ikke mindst på grund af den tiltagende risiko for en global miljøkatastrofe, som de traditionelle policy-systemer ofte måtte give op overfor. Risikobegrebet var en kærkommen fornyelse i politisk sociologi, men Becks analyser animerede også til kritiske reflektioner om hvorvidt, der egentligt var tale om nytænkning.

- Sociologi havde som empirisk fagdiciplin brug for metodisk fornyelse i forhold til modernitetsfor andringernes hastighed og uforudsigelighed.

Giddens havde allerede i The Constitution of Society (1984) påpeget den ortodokse sociologis metodologiske træghed i forhold til senmodernitetets forandringsturbulens. For Giddens blev svaret hans strukturationsteori og dobbelthermeneutik med vægt på dialogen mellem individ og samfund som metodologisk alternativ.

\section{- Både Becks og Giddens} værker var - uanset hvad man måtte mene om deres argumentations plausibilitet - et reflekteret forsøg på at bryde de sociologiske problemstillingers nationale horisont.

Det er derfor et aktuelt initiativ, at Forlaget Sociologi har udgivet antologien $R i$ siko, politik og miljø $i$ det moderne samfund, hvor en række danske og udenlandske samfundsforskere - incl. Ulrich Beck - diskuterer risikobegrebet og dets teoretiske, politiske og samfundsmæssige implikationer i et kritisk perspektiv. At der er tale om en uafklaret kontrovers, er antologien selv et vidne om.

Antologien er delt op i 5 afsnit. I del 1 introduceres Becks projekt teoretisk. Klaus Rasborg diskuterer risikobegrebet gennem opklarende sammenligninger til Giddens og Luhmanns systemteori. Der argumenteres for, at der i de seneste år på en række afgørende punkter gør sig en stigende teoretisk konvergens gældende mellem de tre forfattere, men det påpeges også afslutningsvis, at risikobegrebet, som det foreligger i dag, er præget af inkonsistenser, som må afklares, hvis det skal danne grundlag for opstilling af en plausibel sociologisk teori om risikosamfundet.

Også Torben Hviid Nielsen analyserer Beck, Giddens og Luhmann komparativt med udgangspunkt i refleksivitet, som alle tre forfattere anser som et specifikt episteme ved senmoderniteten. Modernitetens forandring og moderne risici bevæger sig ikke kun på det sociale plan på grund af ny teknologi og andre omverdensfaktorer. De foregår også i individernes hoveder og kulturelle orienteringer. Med henvisning til bl.a. den tyske kultursociolog Gerhard Schultzes post-Bourdieuske analyser i Die Erlebnisgesellschaft (1992), der har været overset i den danske sociolo- giske debat, peger Hviid Nielsen som den eneste i bogen på, at risici i nutidens oplevelsessamfund sætter sig igennem som psykofysiske ændringer i de enkeltes liv. Risici og modernitetsforandringer determineres således i højere grad af de kulturelle scener end af de sociale levevilkår.

Finn Hansson peger på risikodymamikkens manglende kritiske potentiale til at kunne indkredse og fastholde den kapitalakkumulation, der dybest set er omdrejningspunktet også i risikosamfundets udvikling. Dette svækker risikobegrebets civilisationskritiske element, idet både Beck og Giddens - og dermed New Labour, som begge solidariserer sig med politisk - overser risikosamfundets kapitalistiske karakter. De særlige former og modsigelser som kendetegner den kapitalistiske produktion og hele samfundet under det andet moderne og globaliseringsprocessen, antager ofte en tåget karakter.

Bogens teoretiske afsnit afsluttes med en artikel af den finske professor i socialpolitik Risto Eräsaari, som ganske rigtigt peger på, at Beck i sine seneste bøger og artikler i stigende grad lægger vægt på de positive fremtidshorisonter i risikosamfundet. Derfor er der måske større videnskabeligt potentiale $i$ at tematisere risikosamfundet som et mulighedssamfund.

I antologiens 2. del tematiseres risikosamfundets politiske felt og dynamikkerne 
i den politiske kultur. Udgangspunktet er en oversættelse af Beck artikel Subpolitics. Ecology and the Disintegration of Institutional Power fra 1997. Essensen i Becks politiske civilisationskritik er, at de traditionelle politiske systemer ikke kan løse risikosamfundets problemer. De nye risici såsom atom- og miljøkatastrofer skabes af udenomsparlamentariske subkulturelle konstellationer indenfor videnskab, industri, ekspertinstanser etc. Og det er også i disse nye institutionelle organisationsdannelser, at eventuelle løsninger på problemerne skal findes. I forhold til de nye risici slår hverken de traditionelle parlamentariske politikformer eller sociale bevægelser i civilsamfundet til. Beck efterlyser nye institutionelle måder at håndtere de miljømæssige risici på.

Becks diagnose minder om den dobbeltstrategi, som alle politiske bevægelser har måtte lægge til grund for deres arbejde for at realisere politiske mål, hvad enten de gik ud på at skabe lighed, frihed og demokrati eller afværge truende katastrofer som atomkrig, forurening etc. Heri er der ikke noget nyt. Det er præcist hvad kapitlets øvrige forfattere griber fat i. Jørn Loftager påpeger nødvendigheden af både at satse på de etablerede politiske institutioner og det, som Beck kalder det subpolitiske. Problemet med Beck er, at han overser: "hvordan den politiske offentlighed konstitutivt hænger sammen med eksistensen af et skel mellem på den ene side et (delvist) autonomt civilsamfund og på den anden side en politisk myndighed" (Loftager 1999:138).

Henrik Kaare Nielsen ligger på linie med denne kritik og peger på, at teorien om subkultur udgrænser de politiske muligheder og potentialer, som ligger i den kritiske teoris begreber om politisk offentlighed, der netop påpeger samspillet mellem parlamentarisk og udenomsparlamentarisk politik. Derfor er det nødvendigt $i$ en analyse af politiseringsprocesserne $i$ højtudviklede moderne samfund at overskride Becks pragmatiske position og tillægge de institutionelle læreprocesser og erfaringsdannelser i civilsamfundet større betydning.

Gorm Haste argumenterer for, at det i højere grad er lykkedes Luhmann i Soziologie des Risikos (1991) at udvikle en mere konsistent metodisk tilgang til at forstå nutidens politiske udfordringer gennem dennes analyser af de risici, som knytter sig til de adskilte kommunikationssystemer i det senmoderne samfund, der ligesom supertankere har svært ved at skifte retning.

I del 3 om risikobegrebet $i$ tysk og fransk sociologi leverer Anni Greve et befriende anarkistisk orienteret bidrag om den franske tilgang til risikodiskussionen med udgangspunkt i bl.a. Foucault's historiske analyser om magt og viden. Derimod er det de mere systemorienterede muligheder, som knytter sig til risikobegrebet, der diskuteres af den australske sociolog Mitchell Dan i rela- tion til nye styringsteknikker i velfærdsstaten. I bogens sidste to kapitler fokuseres der på belysninger af risikobegrebets anvendelighed $i$ analyser af virksomheder (Kurt Aagaard Nielsen, Jesper Glorien) og miljøpolitik (Jette Rank, Claus Heinberg, Bente Halkier).

Det vil ikke være rimeligt at vurdere de enkelte bidrag enkeltvis. De bør hver især vurderes på egne præmisser. Personligt finder jeg især afsnittet om risiko og politik spændende. For det første forbi det er sjældent, at politik og demokrati diskuteres i dansk sociologi. For det andet fordi Loftager og Kaare Nielsen sætter et yderst relevant spørgsmålstegn ved Becks politiske diagnose om subpolitikkens potentialer og muligheder. På det punkt forekommer Beck at være ligeså naiv som Giddens i dennes globale sværmerier. Det er også inspirerende at opleve, at en konsekvent kapitallogisk analyse af Finn Hansson enkelt og overskueligt kan bringe risikodynamikkens kapitalismelegitimerende skær frem i lyset.

Som kultursociolog savner jeg et par kapitler, som teoretisk og empirisk udfolder og diskuterer risikobegrebet i relation til det højmoderne samfunds kulturelle problemstillinger. For sagen er jo, at risikomomentet ikke kun omfatter miljø, produktion og styringsmekanismer i velfærdssamfundet. Risiko indgår som en væsentlig del i det højmoderne samfunds kulturelle hverdag i form af identitetstab og ontologisk usikkerhed. Der er eksisten- 
tielle problemstillinger af stor social og politisk betydning $\mathrm{i}$ det kulturelle risikosamfund, som det er væsentligt også at reflektere sociologisk.

Gorm Haste kan have ret i, at Luhmann måske rummer større potentialer for oparbejdelsen af en kritisk sociologi om den globale modernitet. Det gælder også i forhold til den æstetiske dimensions betydning for globaliseringsprocessen, idet Luhmanns andre steder i sin systemteori søger at oparbejde denne (Luhmann, Niklas 1997: Die Kunst der Gesellschaft. Frankfurt a.M.: Suhrkamp)

Men dette personligt oplevede savn skal ikke tilsidesætte, at bogen er en præcis introduktion til risikobegrebet og de aktuelle modernitetetsforandringer. Som en analyse af højmodernitetens konturer er bogen central. Der findes næppe en grundigere introduktion af risikobegrebet og dets politiske anvendelighed. Derfor er bogen et centralt og længe savnet redskab i dansk sociologi. Dens systematiske referencer og kritiske tilgang gør den velegnet til undervisningsbrug i både samfundsvidenskab og humaniora. Derimod er den nok for abstrakt til at kunne vinde genklang i den politiske debat trods bogens empiriske afsnit.

\section{Peter Duelund}

Institut for Litteraturvidenskab, Københavns Universitet
Manni Crone: Etikkens genkomst -en udfordring for sociologien? Kobenhavn: Ph.d. - afhandling Sociologisk Institut, 2000 (252 s.)

Vissa hävdar, som bekant, att sociologin är en flerparadigmatisk vetenskap. Andra menar att den är förparadigmatisk. Det första intrycket av Manni Crones avhandling ger de senare rätt. Det är omöjligt att placera den i några av de bekanta sociologiska paradigmen. Man frågar sig; när till och med Ph.d. avhandlingar är revolutionära, vem $i$ all världen skall bedriva normalvetenskap? Sociologin ser ut att vara en krisvetenskap. Den gör konstant uppror mot sig själv. Efter neo-marxism, postmodernism och neo-aristotelism (kommunitarism) är det nu - om man följer Crone - neoplatonismen som står på tur att utmana sociologin.

Men detta första intryck stämmer inte riktigt. I avhandlingen spelar den i USA inflytelserika och kontroversiella, men i Skandinavien ännu relativt okände tyskamerikanske politiske filosofen Leo Strauss huvudrollen. Crone håller honom hårt $\mathrm{i}$ handen. Ja, hon släpper inte taget för en enda sekund. Man skulle därför ändå kunna påstå att hon bedriver normalvetenskap, men det visar sig först om man tänker sig att paradigmer inte behöver vara begränsade till akademiska discipliner. För att kunna inplacera Crone på den akademiska kartan räc- ker det inte ens att gå till generell samhällsteori. Vi måste snarare föreställa oss överordnade filosofiska paradigmer eller kanske till och med världsåskådningar. Vi skulle i detta sammanhang kunna - som till exempel den italienske sociologen Alessandro Ferrara (Reflective Authenticity 1998) - tala om ett "vi" i betydelsen av den västerländska kulturen. Ferrara hävdar att "vi" idag kan liknas vid en karavan som står på en vadplats i en flod. Bakom om oss har vi den tidiga modernitetens säkra strand. Framför oss ligger en strand som vi vet mycket lite om. Här står den västerländska kulturens karavan och tvekar, ty, skriver Ferrara (3), "a great confusion reigns among our guides". Titeln på Crones avhandling är således delvis missvisande. Den handlar inte speciellt mycket om sociologi. Som många andra Querdenkers tycks hon snarast ha varit tvungen att uppfylla vissa formella och oformella akademiska kriterier för att kunna få tillåtelse att skriva om det hon egentligen är intresserad av, nämligen guider eller vägvisare (eller herdar, för att tala med Heidegger) som gör anspråk på att leda den västerländska karavanen in på rätt spår. Leo Strauss var en sådan vägvisare.

$\mathrm{Nu}$ är naturligtvis sociologin en del av den västerländska kulturen och den skulle därmed i någon mening kunna låta sig ledas av vägvisares visdomar. I avhandlingen blir det dock aldrig klart vad detta skulle innebära i Strauss fall. Crone läm- 
nar sociologin efter ett inledande kapitel och kommer egentligen aldrig tillbaka. Hennes avhandling förblir i första hand metadisciplinär. Också på denna nivå skulle man alltså kunna tala om paradigmer. Crone tar parti för, introducerar och argumenterar för ett av dessa vägvisarparadigmer. Ferrara - och på denna punkt är han inte särskilt originell - skisserar fyra olika sådana paradigmer. Det första säger att den västerländska karavanen bör vända tillbaka till den säkra strand vi just har lämnat bakom oss: Tillbaka till det tidiga moderna, till instrumentell rationalitet, positivism och social ingenjörskonst! Kritiska rationalister, analytiska marxister och rational choice teorins företrädare kan ses som exempel på denna typ av vägvisare. En andra grupp vill gå längre tillbaka än så. De vill tillbaka till Aristoteles och Platon. Medan den tidiga moderniteten byggde på en föreställning om ett subjektivt förnuft (i Descartes och Kants mening, dvs. förnuftet som det mänskliga subjektets egendom), vilade det antika Greklands kultur på ett objektivt förnuft. Det handlade då inte om ett epistemologiskt förnuft, utan om ett ontologiskt förnuft. Det uppfattades som en egenskap hos naturen. Här kan nämnas Alasdair MacIntyre, Charles Taylor och i skiftande grad hela den kommunitaristiska traditionen. Hit bör också Leo Strauss räknas - och därmed Manni Crone. En tredje grupp av vägvisare är de postmoderna (Derrida, Foucault,
Rorty, etc.). De menar, skriver Ferrara, att vi varken skall vända tillbaka till gamla stränder eller vada fram mot nya. Vi skall bosätta oss på husbåtar och glida med i flodens mer eller mindre vilda ström. Föreställningen om ett autonomt förnuft är det första som faller överbord. Den fjärde gruppen vill att vi skall ta oss över till stranden på andra sidan. Ferrara nämner Habermas och Rawls. Här handlar det varken om ett subjektivt eller objektivt förnuft utan om ett intersubjektivt. Det är i denna vägvisardiskurs snarare än i en sociologisk eller ens samhällsteoretisk diskurs som Crones avhandling skall placeras.

Den typ av vägvisning som vi här talar om är i någon mening alltid etisk, ty den inbegriper de mål som vi bör eftersträva, dvs. en diskussion om det goda. De fyra vägvisarparadigmen är visserligen etiska på olika sätt, men de är alla - explicit eller implicit - etiska. Jag tror därför Crone har fel när hon i det första kapitlet ofta ger intrycket av att sociologin och etiken ömsesidigt har uteslutit varandra. Problemet med en sådan tes är för det första att den på Baumanskt vis reducerar sociologin i sin helhet till det första vägvisarparadigmet. (I Crones framställning saknar man framförallt Alfred Schütz. Han har - både intellektuellt och personligt - en bakgrund som påminner om Strauss, men har till skillnad från Strauss i hög grad och under lång tid påverkat sociologin.) Webers tes om vär- deneutralitet blir för Crone paradigmatisk för hela sociologin. Det ligger naturligtvis en del i detta. Genom att omvandla moral till moraliska fakta fann sociologin sin identitet gentemot den praktiska filosofin. Men vilken sociolog tror idag att vetenskapen kan vara fullständigt värdeneutral? Sociologin har generellt sett gjort upp med denna föreställning åtminstone sedan slutet av 60-talet. Det har producerats tonvis med sociologi utan tro på värdeneutralitet; neomarxism, postmodernism, kommunitarism, "kvalitativt" orienterade empiriska undersökningar, etc. För det andra tror jag inte (och just detta har kritiken av tesen om värdeneutralitet om och om igen visat) att positivistisk vetenskap i praktiken var värdeneutral. Den var snarare en del av den tidiga moderniteten, vilken byggde på en utilitaristisk eller materialistisk etik. Det visade ju för övrigt på ett paradoxalt sätt redan Weber. Det intresseväckande i Crones avhandling ligger, enligt min mening, således varken $i$ kritiken av värdeneutralitet eller i den begränsade sociologiska diskursen, utan snarare i diskussionen om vilken typ av etik som kan visa oss Vägen. Den negativa utgångspunkten är då den nietzscheanske Weber, dvs. etik som decisionism, subjektiveringen av det goda, etikens nollpunkt.

I kapitel 2 kritiserar Crone en livskraftigare position än den värdeneutrala, nämligen historicismen. Under denna rubrik inbegripes allt från aristotelisk phronesis (inklu- 
sive kommunitarism), över Heideggers varahistoria, till postmodern konstruktivism. Det handlar här om en kontextualisering av förnuftet. Det ser Crone bara som en variation på det subjektiva förnuftets tema. På samma sätt som för Webers subjektiva etik gäller för historicismen att den i grund och botten inte kan värna sig mot relativism och nihilism.

Resten av avhandlingen (kapitel 3-5) begränsar sig till en diskussion av den position jag här har kallat det andra vägvisarparadigmet. Medan vi under de senaste två årtiondena har sett en uppblomstring av neo-aristotelismen, menar Crone att vi i högre grad bör vända oss till Platon. Det är detta som är det originella och överraskande med denna avhandling. Platon har ju varit något av en strykpojke i efterkrigstidens filosofi från Popper till Rorty. Crones grundläggande poäng är emellertid övertygande. Aristoteles skiljer strikt mellan naturfilosofi och etik och begränsar det objektiva förnuftets relevans till det förra. Vad gäller det senare får vi förlita oss till phronesis, dvs. en form av förnuft som drabbas av historicismens kontingensproblematik. Platon betonar däremot möjligheten av ett objektivt praktiskt förnuft. Han relaterar, hävdar Crone, etiken till en specifik form av natur, nämligen den mänskliga. Den grundläggande tesen och konklusionen blir därmed att vi bara kan undgå etisk relativism och nihilism genom att relatera etik till den mänskliga naturen och den objektivt förnuftiga normativitet som finns inneboende i den. Därmed har vi också - så tolkar jag Crone i Platon/Strauss funnit de vägvisare som kan leda den västerländska karavanen på rätt spår.

Jag tror Crone har rätt i sin kritik av alla former av historicism som avvisar föreställningen om en mänsklig natur. Etiken måste stödja sig på en antropologi för att undgå nihilism. Men längre än så (vilket dock är långt) förmår, enligt min mening, avhandlingen inte att övertyga. Problemet med Platon är att han inte utvecklar en formell teori om det goda livet utan en substantiell. Den lämnar därmed alltför lite utrymme åt individualism och pluralism. Crone ignorerar den liberala kritiken av kommunitarismen - dvs. argumentet att det rätta har prioritet framför det goda - och riskerar därmed att förespråka en totalitär ideologi. Det goda livet har, enligt Platon, två former; den politiska och den kontemplativa, varav den senare räknas som högre stående än den förra. Men varför just dessa former? Jag kan inte se annat än att Crone påstår att den kontemplativa livsformens etiska överhöghet följer av människans natur, men hon visar det inte. Varför är det eviga, det välordnade, det harmoniska absoluta värden? Varför kan vi inte lika gärna uppfatta Talking Heads påstående "Heaven is a place were nothing never happens." - som ett avgörande argument? Eller varför skall vi inte tro på Ferraras tes (72) att "... the only thing which for 'us' ... counts as unconditionally good is the possesion of a 'good identity' a fullfilled identity". En sådan föreställning har den fördelen att den tillåter individualism och pluralism utan att slå över i relativism och nihilism. Ett annat problem är hur Crone/Strauss undgår att kritiken av historicism leder över till naiv realism. Det är inte oproblematisk att tala om den mänskliga naturen. Enligt min mening måste vi kunna göra det utan att ignorera den lingvistiska vändningens landvinningar. Det som dock oroar mig mest är Crones spridda kritik av egalitarism. Enligt min mening borde - redan av logiska skäl - en etik som utgår från den mänskliga naturen vara universell $\mathrm{i}$ den meningen att ett gott liv är möjligt för alla människor. Men enligt Strauss/Aristoteles/Platon/Crone tycks det vara så att "visse mennesker af natur (er) mer disponerede for moral end andre". (164) Vad betyder detta? Har bara vissa människor förutsättningar för att leva det goda livet? Och betyder detta också att bara vissa människor kan ha rätt till det goda livet? Crone kan väl inte gärna mena att ett gott samhälle är ett samhälle där t.ex. kvinnor och slavar exkluderas från det goda livet? Rawls hävdar att om några människor har missgynnats av naturen är det de välgynnades skyldighet att avstå delar av sitt överflöd till de missgynnande. Är det verkligen sådana rättviseföreställningar som Crone tar avstånd från genom att tala om "lighed (som) ... vort 
samfunds højeste fordom" (160) och plädera för en "inegalitaristisk" moral (164)? Strauss kontroversiella elitism tycks här accepteras utan kritisk diskussion. En besläktad punkt är Strauss skarpa distinktion mellan filosofi och politik. Bara en viss typ av människor har tillgång till förnuftet, nämligen filosoferna och de bör vända sig från det obotligt oförnuftiga samhällslivet. Här förenas konservatism och elitism med antimodernism. Också på denna punkt är Crone överraskande okritisk. Själv kan jag inte se annat än att föreställningen om en mänsklig natur är en universalistisk kategori och detta utesluter alla former av elitism.

I det stora hela är det emellertid en imponerande avhandling som Crone har skrivit. Den sträcker sig från försokratiker till postmodernister. Den introducerar på ett förtjänstfullt sätt ett viktigt författarskap som är relativt okänt i Skandinavien. Den fångar vår tids nihilistiska problematik i ett nötskal. Den kritiserar övertygande positivism och historicism och pekar, enligt min mening, i rätt riktning när den efterlyser en filosofisk antropologi. Jag hade dock önskat mig en större kritisk distans till läromästaren Strauss, jag skulle vilja ha sett en diskussion av svårigheterna att tillämpa antik filosofi på dagens samhällssituation och jag skulle gärna vilja att Crone med de nya erövrade kunskaperna i bagaget hade vänt tillbaka till sociologin. Som det nu är får vi aldrig riktigt veta på vilket sätt den strausska etiken utmanar sociologin.

\section{Mikael Carleheden}

Institut for sociale forhold og organisation, Aalborgs universitet

\section{Üzeyir Tireli: Hver- dagens erobring. Etniske minoritets- unge i europaiske storbyer. Koben- havn, Hans Reitzels Forlag, 1999 (236 s.)}

Hverdagens erobring handler om kontrasterne i samtiden. Intentionen med denne bog er at bidrage til belysningen af nutidens kompleksitet med fokus på etniske minoritetsunges hverdagserfaringer og handlingsovervejelser i en række europæiske storbyer. Gennem formidling af unges hverdagserfaringer, syn på kæreste- og venskabsforhold samt kulturelle begrænsninger i forhold til udfoldelsesmuligheder undersøges det opbrud, der rent faktisk finder sted i multikulturelle metropoler. Det bliver således de unges oplevelser af den multietniske udvikling, deres måde at forholde sig til nyracistiske tendenser, etableringen af intimrelationer samt artikuleringen af nye identitetskonstruktioner, der bliver genstandsfeltet for en forståelse af de modsætninger, paradokser og ambivalenser, der præger etnisk minoritetsungdoms hverdagsliv.

Den multietniske udvikling i europæiske byer illustrerer både multikulturalis- me, blandingskultur og hybridkultur - men også tendenser til nyracistiske bevægelser. Forandringsprocesserne i det sociale liv - ikke mindst hvordan den samfundsmæssige udvikling kommer til udtryk i etniske minoritetsunges identitetsdannelsesproces belyses gennem følgende spørgsmål: 1) Hvordan oplever etniske minoritetsunge den multietniske udvikling i deres hverdag? 2) Hvordan håndteres nyracismen, intimrelationerne, herunder venskaber, og de nye identiteter i de multietniske bydele?

Som det fremgår af spørgsmålene er der tale om en omfattende bog, hvilket resulterer i, at man som læser mangler teoretisk og begrebsmæssig præcisering af begreber som nyracisme, identitet, multietnicitet m.m. Ligeledes kunne man som læser have ønsket en yderligere begrænsning af selve genstandsfeltet således at man som forfatter havde valgt at fokusere på enten transnationalt- eller etniskorienterede identitetssøgeprocesser. Til gengæld er bogens styrke dets empiriske fokus, hvilket gør bogen læseværdig. Empirisk er der tale om formidling af situationsbilleder af vilkårligt udvalgte unge med en islamisk baggrund i alderen 16-28 og som er opvokset i vesteuropæiske storbyer. Med udgangspunkt i Københavns multietniske bydele relateres unges erfaringer med dataindsamling fra Amsterdam, Berlin og London - i alt 95 interview i form af enkelt- og gruppeinterview. 
Bogen kan samtidig opfattes som et situationsbillede af et snævert udsnit af etnisk minoritetsungdom, hvor de multietniske udviklingstendenser ikke nødvendigvis forløber problemfrit. Interviewene i København og Berlin viser, at unge på den ene side opfatter byen som et rum, hvor der er rige muligheder for nydelse, underholdning og æstetik, mens den på den anden side fremstår som en rumlig adskilt sfære, da nogle af byens forlystelsessteder direkte begrænser minoritetsunges adgang hertil. Der er derfor tale om et modsætningsforhold mellem en tiltrækning af storbyens muligheder og fornøjelser, spændinger og erfaringsrigdom, samtidig med en konkret og symbolsk afvisning fra disse erfaringsmuligheder.

Gennem hele bogen rejser Tireli spørgsmålet om, hvad der karakteriserer mødet med Den Anden, samt hvilke vanskeligheder og barrierer de unge støder på i deres bestræbelser på at være medlemmer af det omkringliggende samfund? Formålet er at belyse udviklingstendenser i minoritetsunges hverdagserfaringer herunder den enorme kompleksitet $\mathrm{i}$ interetniske og interraciale relationer. Det centrale ved diskussionen af tværetniske venskabers muligheder i et komparativt perspektiv er de eksisterende ambivalenser, da majoritetssamfundet forholder sig både åbent og afvisende overfor etniske minoritetsunge.

Virkeligheden er mangetydig og de unge fremhæver da også et ønske om et multikulturelt samfund, hvor de har mulighed for at være sig selv og udtrykke deres forskellige identiteter i de multietniske bydele. Tireli understreger sidst i bogen, at det moderne urbane liv og de nye sociale praksisser i en etnisk minoritetssammenhæng betyder, at der ikke længere findes et udgangspunkt hvorfra meningen og adfærdsnormen konstrueres. Situationen af ubestemthed og tilfældighed medfører i stedet at det enkelte etniske minoritetsmedlem selv må skabe mening i sin hverdag.

Fremkomsten af nye identiteter og kulturer afhænger af de unges hverdagserfaringer, forhandlinger og ikke mindst deres evne til at udnytte byens muligheder til at individualisere deres personlige liv. Det er overvejende disse erfaringer og de eksisterende interaktionsmuligheder i de forskellige lokalsamfund, der får betydning for de kulturelle og identitetsmæssige transformationer. Bevidstheden om de eksisterende muligheder, værdisystemer og kontakter, som de unge har til rådighed, samt bevidstheden om muligheden for at manipulere disse værdier resulterer primært i to reaktionstendenser: 1) en transnationalt-orienterede identitetssøgeproces, dvs. en distancering til det etniske tilhørsforhold eller 2) en etniskorienterede identitetssøgeproces, dvs. en rekonstruktionsproces af det etniske tilhørsforhold som følge af den sociale og økonomiske eksklusion.
I lighed med den ny forskningsmæssige tilgang herhjemme, der først og fremmest repræsenteres af Flemming Røgilds og Yvonne Mørck, viser Tirelis undersøgelse, at der opstår nye livsstile og orienteringer i storbyens kraftcentre. De nye livsrytmer i de multietniske bydele såvel som de mellemmenneskelige relationer centreres i høj grad omkring en transkulturel akse. Det er primært ressourcerige unge, der dominerer den transnationalt-orienterede identitetssøgeproces. De er ikke alene velartikulerede angående nationale og internationale forhold, men også i stand til at informere om deres baggrund og oprindelse i en metakontekstuel sammenhæng. I modsætning til majoritetsbefolkningens monokulturelle syn på identitetskonstruktionen orienterer de sig på tværs af geografiske og kulturelle grænser. Beherskelsen af flere sprog og anvendelsen af elektroniske kommunikationsmidler til at overskride grænserne medfører, at deres orientering spænder på tværs af kontinenterne.

Med udgangspunkt i deres kulturelle kapital adopterer og transformerer de tids- og rumligt adskilte kulturelle fænomener, så de opnår en ny syntese. Den kulturelle syntese som udtrykkes og konstrueres gennem den transnationalt-orienterede identitetssøgeproces viser sig primært inden for den æstetiske og kulturelle sfære. Tireli fremhæver, at disse unge ikke alene er potentielle symbolskabere for unge i al- 
mindelighed. De opretter tilmed deres eget sociale system og baserer primært deres arbejde på en kulturel sfære, som ikke varetages tilstrækkeligt af de eksisterende sociale systemer. Disse unge er således i færd med at konstruere nye etniske og sociale identiteter i spændingsfeltet mellem det gamle og det nye, det kendte og det ubestemte:

\section{„Der er et naturligt møde og en dialog mellem etniske mi- noritetsunge og tyske unge. De går meget sammen på tværs af etniske grænser, de identificerer sig f.eks. med hip-hop-musik- ken eller andre grene af den populære kul- tur. De er i stand til at negligere deres natio- nale baggrund. Paral- lelt med denne udvik- ling findes der også nationale foreninger og klubber, som er et resultat af diskrimina- tionen i de tyske klub- ber.(...). Efter Øst- og Vesttyskland blev genforenet, så føler etniske minoriteter \\ Den etnisk-orienterede identitetssøgeproces fore- kommer imidlertid hyppi- gere end den transnationalt- orienterede. Og det som føl- ge af den sociale og økono- miske eksklusion der med- fører, at mange vender blik- ket mod deres „etniske res- sourcer“. Unge samles såle- des i grupper med henblik på at finde et fælles ståsted i for- hold til den tiltagende nyrac- isme i Vesteuropa. Gennem kollektiv organisering forsø- ger de at svare igen på mar- ginaliserings- og arbejdsløs- hedssituationen ved at rede- finere deres rolle og selv- forståelse gennem fællesska- ber, hvor de henter inspira- tion og handlingsanvisninger fra deres etniske og religiøse baggrund.} en slags afmagt, og de er begyndt at vende tilbage til deres etniske grupper med en styrket nationalfølelse, som kommer til udtryk i flere foreningsdannelser, mindre lyst til at omgås tyskerne og mindre lyst til intimrelationer", fortæller en respondent (1999:126).
Som det fremgår af citatet er der tale om to reaktionstendenser. Tireli understreger, at den transnationalt-orienterede identitetssøgeproces primært bygger på antiracismen. Bekæmpelsen af racediskriminationen og nyracistiske tendenser i samfundet udgør dermed grundlaget for ressourcerige unges håndtering af hverdagslivet og valg af overlevelsesstrategier.

Denne gruppe af unge er $\mathrm{i}$ færd med at rekonstruere en ny identitet, der ifølge Tireli kan betegnes en negationsidentitet, da de tager afstand fra de vestlige værdier, som $i$ deres øjne er symboliseret ved diskrimination, udstødelse og normløshed. Etniske minoritetsunge, der ikke har fået en tilsigtet plads i fællesskabet, begynder i stedet at søge nye "substantielle" identiteter og strategier, hvor de opstiller broderskabet og Islam som et modstykke til nyracismen og den postmodernistiske fragmentering. Den etniske fanatisme, der er affødt af den nyracistiske fremmarch, inkorporeres i disse rebelske gruppers positionering. De forsvarer forestillingen om „etnisk autenticitet" bl.a. ved at samarbejde med en række nationalistiske bevægelser. Med udgangspunkt i det religiøse og etnisk-nationale tilhørsforhold forsøger de at beskytte sig mod den fragmenterende livsform og storbysamfundets flerkulturelle påvirkninger. De forsøger således at knytte bånd til den "oprindelige" kultur bl.a. gennem en tydeliggørelse og markering af deres religion og forkærlighed for „fædrelandet".

Det største problem er imidlertid at Islam og det etniske tilhørsforhold som et udskillelsesparameter ikke alene anvendes af unge som et modstykke mod marginaliserings- og arbejdsløshedssituationen - men også i den politiske diskurs, hvor forskelsbehandlingen retfærdiggøres med henvisningen til "de fremmedes" anderledes kultur. Den politiske og nyracistiske konstruktion mod etniske minoritetsgrupper, der i forvejen er svagt stillede socio-økonomisk, artikuleres i kulturalistiske termer. Det er primært unge fra Mellemøsten der refereres til, når den kulturelle forskellighed problematiseres og kritiseres som en barriere for integrationen i samfundet. Skabelsen af nye (eller gamle?) fjende- 
billeder i Vesten konstrueres således gennem en nyracistisk diskurs, hvor italesættelsen af de kulturelle forskelle og det etniske tilhørsforhold fremstår som en barriere for udbygningen af sociale relationer. Eftersom bogen først og fremmest henvender sig til folk, der i praksis arbejder med etniske minoriteter, så udelades teoretiske refleksioner over brugen af begreber som "den nye racisme". Som læser savner jeg både litteraturhenvisninger til begrebet "den nye racisme" samt teoretiske og sociologiske refleksioner over dette begreb - ikke mindst når det rent faktisk indgår i problemformuleringens spørgsmål. I stedet belyser Tireli nyracisme og dialogen med Den Anden gennem holdninger til arbejdsfællesskabet, arbejdsløsheden og den institutionelle diskrimination, der udgør et centralt problem blandt unge i alle de undersøgte byer.

Etnisk minoritetsungdom fastholdes i en underposition, hvor de arbejds- og uddannelsesmæssigt har svært ved at udvise social mobilitet. Ikke mindst i Tyskland erfarer unge, at uanset deres høje uddannelsesniveau og europæiske livsstil, så opretholder visse kredse i Tyskland alligevel en distance til dem. Problemet med at få fodfæste på arbejdsmarkedet som en konsekvens af manglende kvalifikationer eller en anderledes kulturbaggrund er ikke i stand til fyldestgørende at forklare etniske minoritetsunges arbejdsløshed. Tireli understreger, at diskriminationsaspek- tet og den holdningsmæssige barriere bør indgå som et vigtigt element i diskussionen af etniske unges ledighed.

Med fokus på holdninger til arbejdsfællesskabet og vanskelighederne ved etableringen af sociale fællesskaber mellem danske og etniske minoritetsunge belyses unges arbejdsrelationer. Tendensen er, at dialogen og kontakten er etnisk præget, da det primært er gennem det etniske fællesskab, der findes og konstrueres på arbejdspladsen, at man artikulerer sine holdninger og gør sin indflydelse gældende. I de enkelte tilfælde hvor der rent faktisk dannes tværetniske venskaber, så forekommer der ofte en form for skæbnefællesskab. Grundlæggelsen af sociale fællesskaber tager her udgangspunkt i en fælles fortolkning af omverdenen, hvor følelsen af at være anderledes, marginaliseret og ekskluderet fra fællesskabet på arbejdspladsen bliver udgangspunktet for en fællesskabsfølelse. Skæbnefællesskabet bliver således et centralt begreb i Tirelis analyse af nye transformationer af mellemmenneskelige relationer. Det viser sig faktisk, at unge fra det etniske mindretal og fra majoritetssamfundet godt kan finde sammen, hvis de befinder sig $i$ samme marginaliserede position.

Det empiriske materiale viser ligeledes at venskabsog fællesskabsdannelserne med Den Anden har bedre muligheder i kærlighedssfæren end på arbejdsmarkedet. Fornyelsesprocessen i de sociale og følelsesmæssige relationer betyder, at specielt etniske minoritetskvinder er i færd med at kombinere det gamle og det nostalgiske med det nye og emancipatoriske. De indgår således i en forhandlingsposition med kæresten og familien om en demokratisering af intimrelationerne. Det er derfor kun på overfladen, at man kan konstatere en gentagelse af forældrenes livsmønster. Ved nærmere iagttagelse ses det, at de unges hverdagsliv er kendetegnet ved en konstant udvikling med fokus på individets autonomi.

Generelt har dialogen og nærrelationerne dog de bedste vilkår internt $\mathrm{i}$ den etniske gruppe. Det er her at minoritetsungdommen ikke alene finder deres nære venner og varige venskaber, men også henter forståelse og indlevelse, loyalitet og uforbeholden støtte, dvs. får respons på deres oplevelser i storbyen. På et overordnet plan konkluderer Tireli, at hverdagslivet i de multietniske bydele ikke nødvendigvis fører til tværetniske venskaber:

"Samtalerne viser, at
der grundlæggende
er interesse for og re-
elle forsøg på dialog
mellem etniske mino-
ritetsunge og majori-
tetsunge, men det
lykkes i relativt få til-
fælde, og derfor har
disse en marginal po-
sition. (...). Der er
snarere tale om social
segregation i den mil-
deste udformning
med lavest muligt 
interaktionsniveau

mellem samfundets

etniske grupper" (1999:

223).

Som det fremgår af citatet er konklusionen på hverdagens erobring herunder brobygningen mellem minoritetsog majoritetsunge en proces, der for størstedelen af unge endnu ikke er lykkedes. Belysningen af etniske minoritetsgruppers hverdagsrelationer og erfaringer gør bogen interessant for en bred gruppe af mennesker med interesse $\mathrm{i}$ hverdagslivet $\mathrm{i}$ multietniske metropoler. Inddragelsen af samtidens modsætninger, paradokser og ambivalenser herunder revitaliseringen af racismen, marginalisering og diskriminationsaspektet gør ikke alene bogen interessant men også yderst aktuelt. God læselyst!

\section{Kathrine Scheel}

\section{Mogens Nygaard Christoffersen: Risikofaktorer $i$ barndommen - en forløbsundersøgelse sarligt med henblik på forældres psyki- ske sygdomme. Kobenhavn: Social Forskningsinsti- tuttet, 1999 (141s.)}

Risikofaktorer i barndommen en forløbsundersøgelse særligt med henblik på forældres psykiske sygdomme er en del af en større undersøgelse under programmet Risikofaktorer $i$ barndommen. Formålet med undersøgelsen er at undersøge risikofaktorernes konsekvenser for børn og unge både med henblik på at beskrive, hvordan det går dem i ungdommen og senere som voksne. Undersøgelsesprogrammet er baseret på en database, der omfatter i alt 155.000 børn født 1966 og 1973. Disse børn og deres forældre er blevet fulgt i en 15 årig periode fra 1979- 1993 og gennemløber således et aldersinterval på henholdsvis 6-20 og 13-27 år. På den baggrund er det undersøgelsens sigte at belyse langtidseffekterne af en lang række risikofaktorer herunder forældrenes psykiske sygdomme for børnene både i deres ungdom og levevilkår som voksne. Bogens styrke er, at den bygger på to hele fødselskohorter frem for stikprøveanalyser, og at disse børn og deres forældre er fulgt gennem en 15-årig periode. Undersøgelser af denne type er sjældne i dansk sammenhæng og væsentlige, da de giver mulighed for at sige noget om langtidseffekterne. Kritisk kan anføres, at idet rapporten undersøger statistiske effekter af allerede udpegede og kendte belastningsforhold, er der langt mellem de overraskende resultater.

Et af de overraskende resultater fra undersøgelsen er, at der ikke kan påvises særligt robuste statistiske sammenhænge mellem forældres psykiske sygdom og belastninger i barndommen. I mod forventning viste det sig, at forældrenes psykiske sygdom kun kan tilskrives en relativ lille del af forhold såsom barnets forhøjede dødelighed, psykiske lidelser, destruktive adfærd, anbringelse uden for hjemmet m.v. I første kapitel sammenfattes disse resultater vedr. belastninger i kraft af forældrenes psykiske lidelser. Herudover fokuseres der - vel netop i kraft af disse resultater - ikke i nævneværdig grad på denne problemstilling, som man ellers kunne forvente givet rapportens undertitel.

Rapporten består af elleve kapitler. Det første kapitel er en sammenfatning af undersøgelsens antagelser og resultater, hvor læseren har mulighed for at skabe sig et overblik. Dette kapitel er væsentligt, fordi det fremtrækker de centrale konklusioner fra undersøgelsen på en sammenhængende måde. Det sidste kapitel er en redegørelse for undersøgelsesmetoden, mens de resterende ni kapitler udgør selve analysen af de forskellige risikofaktorer. Disse kapitler er alle bygget op omkring en eller flere tabeller. Andet, tredje og fjerde kapitel belyser forekomsten af belastninger, for tidlig død hos børnene og årsagerne hertil samt omsorgssvigt og anbringelse. Kapitlerne fem til ni fokuserer på psykiske lidelser, kriminalitet, narkotikamisbrug, sædelighedsforbrydelser og selvmord hos børnene og de unge fra de to årgange. Kapitel ti omhandler sammenhænge mellem forældres alkoholisme og psykisk lidelser. På grundlag af de ni kapitler, der udgør selve analysen, tegner der sig et 
billede af en række gennemgående belastningsfaktorer i barndommen såsom forældres misbrugsproblemer, andre former for selvdestruktive adfærd (selvmord og selvmordsforsøg), vold i familien - specielt vold og overgreb mod barnet, og en marginaliseret tilknytning til arbejdsmarkedet. I det følgende vil jeg fremdrage forskellige sammenhænge fra undersøgelsen, som jeg har hæftet mig ved vedr. anbragte børn og betydningen af en marginaliseret tilknytning til arbejdsmarkedet.

\section{Anbragte børn}

En væsentlig statistiske sammenhæng at hæfte sig ved er langtidseffekterne af en anbringelse uden for hjemmet. Eksempelvis er der en forhøjet statistisk risiko for for tidlig død for gruppen af børn anbragt uden for hjemmet. For 1966- årgangen er risikoen i den undersøgte periode 3-4 gange større end for deres jævnaldrende! Med henvisning til tidligere undersøgelser påpeges desuden en overhyppighed af kriminalitet blandt anbragte børn. Børn anbragt på institution har således dobbelt så stor risiko for senere at få en dom for kriminalitet. Christoffersen sørger her for at kæde de statistiske sammenhænge sammen, opstille en række plausible forklaringer på sammenhængene og diskutere dem i lyset af andre undersøgelser, uden at en enkelt forklaring udpeges som den mest sandsynlige. Det påpeges for eksempel blandt andet, at kriminel adfærd kan være en del af institu- tionsnormerne, og at grunden til anbringelsen er belastede faktorer i hjemmet såsom forældrenes vold mod barnet.

Undersøgelsen viser, at der er tre gange så stor sandsynlighed for manglende selvværd for de anbragte unge, der ikke har kontakt med deres forældre. Undersøgelsen viser desuden, at de udslagsgivende forhold for anbragte unges selvværdsfølelse hovedsagelig bunder i de belastninger, de har været udsat for inden anbringelsen. Igen henvises der til tidligere undersøgelser for herved at kunne uddybe de forskellige statistiske sammenhænge. Eksempelvis henvises der til Christoffersens egen undersøgelse af anbragte børn. Her er det blevet vist, at denne gruppe ikke lever mere alene end deres jævnaldrende, men at de generelt føler sig mere ensomme og langt hyppigere oplever en manglende selvværdsfølelse sammenlignet med den samlede risikogruppe, der indgik $\mathrm{i}$ undersøgelsen.

\section{En marginaliseret tilknytning til arbejds- markedet}

I det indledende kapitel behandles betydningen af en marginaliseret tilknytning til arbejdsmarkedet, som var emnet for den første undersøgelse under programmet: Risikofaktorer i barndommen ("Opvækst med arbejdsløshed"), og dette forhold er et tilbagevendende belastningsforhold $i$ analysen af børn og unges kriminalitet, narkonomi, selvmord etc. En lang række sociale adfærdsmæssige problemer hos de unge tilskrives således enten forældrenes længerevarende arbejdsløshed eller den unges egen korte skolegang og manglende erhvervsmæssige tilknytning. I overenstemmelse med andre repræsentative undersøgelser, viser nærværende undersøgelse større risiko for de unges udvikling af narkomani i familier med belastningsforhold såsom vold, misbrug, kriminalitet og anbringelse uden for hjemmet. På grundlag af fødselskohorten fra 1966 fremgår det eksempelvis, at risikoen for at blive narkoman omvendt er mindre for børn, hvor moderen har fået en erhvervsuddannelse, og det konkluderes, at en relativ stor andel af narkomanerne må tilskrives forældrenes marginaliserede tilknytning til arbejdsmarkedet.

Ifølge tidligere danske undersøgelser øger vold i familien og specielt vold mod barnet, risikoen for barnets selvmordforsøg. Af hyppige forklaringer på selvmordforsøg i øvrigt nævnes incest og seksuelt overgreb, koncentrationsvanskeligheder i skolen, ønske om at komme væk fra hjemmet samt mobning $\mathrm{i}$ skolen. Det fremgår, at det primært er forældrenes og barnets egen skole- og erhvervsmæssige tilknytning, der skaber en robusthed, der mindsker risikoen for de unges selvmordsforsøg. Også på grundlag af tidligere undersøgelser konstateres en markant overhyppighed af selvmordsforsøg for børn af arbejdsløse forældre. At selv- 
mordsforsøg her i særlig grad kan tilskrives moderens marginale stilling på arbejdsmarkedet - og ikke i samme grad faderens - er overraskende og burde kommenteres.

Veldokumenteret faktuel viden Risikofaktorer i barndommen er anden rapport i programmet og er foreløbige forskningsresultater, idet analyserne endnu ikke er fuldt til endebragt. Læses bogen samlet er der mange tal og statistiske sammenhænge at forholde sig til. Mange af de statistiske sammenhænge kan ikke overraske, men det er alligevel væsentligt at få sammenhængene dokumenteret. Mest spændende synes jeg rapporten er, der hvor andre undersøgelser trækkes ind i forsøget på at opstille plausible bud på forklaringer af disse sammenhænge, eller der hvor komplekse problemstillinger behandles. Eksempelvis kan nævnes den lidt bredere anlagte diskussion af omsorgssvigt og anbragte børn i kapitel fire, hvor også spørgsmålet om social arv berøres ganske kort. Her påpeges det ikke overraskende, at visse typer af sociale begivenheder $i$ barndomsårene synes at have vidtrækkende konsekvenser for et voksent liv og relationerne til egne børn. Her kan barnets anbringelse øge risikoen for, at egne børn også senere anbringes. En sådan sammenhæng må skabe incitament til at interessere sig for de processer, der skaber en sådan ond cirkel.

Ind imellem analyseres materialet en smule slavisk, hvorved helt selvfølgelige sammenhænge fremkommer. Helt indlysende konstateres det eksempelvis i kapitel to, at de familiemæssige belastninger er uafhængige af, om familien har drenge eller pigebørn. Afsnittet om mavesår hos alkoholpatienter i kapitel ti virker også mindre relevant. Vi præsenteres for sammenhænge, der efterfølgende tilbagevises (sammenhæng mellem mavesår og psykosomatiske stressreaktioner), og den anden sammenhæng nemlig mellem en alkoholrelateret lidelse og irritation i marve/ tarmsystem forekommer indlysende. Desuden synes vi i dette kapitel om alkoholisme og psykiske lidelser at miste børnene, der er bogens egentlige sigte, lidt af syne.

Rapporten er velskrevet og veldisponeret. Der gøres omhyggeligt rede for de metodiske forbehold, hvormed konklusionerne skal læses, og rapporten fremstår som en sober gennemgang af en række faktuelle forhold aflæst på grundlag af tabelmateriale. Det kan dog alligevel være svært at bevare overblikket i læsningen af den samlede analyse, hvilket må ses som en konsekvens af, at et stort tabelmateriale skal analyseres og præsenteres. Læseren må her sortere mellem de undertiden noget detaljerede oplysninger og hente hjælp i første kapitel, der er en god overskuelig sammenfatning.

Familiens eventuelt svækkede sociale netværk, som må forventes at være en væsentlig risikofaktor, indgår ikke som en variabel i undersøgelsen (andet end som en forventet konsekvens af arbejdsløshed, familieopløsning etc.). Der er tale om en vanskeligt registrerbar belastningsfaktor, som jeg blot nævner for at påpege en svaghed og begrænsning forbundet med en kvantitativ analyse. Belastninger i form af familiens svækkede sociale netværk og udstødelse belyses bedst via dybdegående kvalitative metoder, idet udstødelsesprocessernes sammenhænge er komplekse og ikke nødvendigvis eller udelukkende et resultat af arbejdsløshed og familieopløsning. Med andre ord: Der er tale om en god opslags- og baggrundsbog for blandt andre forskere, politikere og administratorer, der har brug for kvantificeret viden om belastningsfaktorer og deres udbredelse samt hyppigheden af de unges senere adfærdsreaktioner. Men de mange tal og tendenser, der præsenteres i undersøgelsen kan ikke stå alene, når vi skal forstå risikofaktorer i barndommen og diskutere forbyggelsesstrategier.

\section{Inger Glavind Bo,}

Institut for Sociale Forhold og Organisation, Aalborg Universitet 
Ulf Brinkkjær:

Hhx-elevers

habitus og livsstil -en rejse i dannelse,

liv og skole. Kobenhavn: Danmarks Pædagogiske Institut, 2000 (224 s.)

Denne bog beskæftiger sig med den del af ungdomsuddannelserne, som fører til højere handelseksamen (hhx). Som titlen signalerer skulle bogen først og fremmest handle om hhx-elevers habitus og livsstil. En problemstilling, der af Ulf Brinkkjær (UB) formuleres som "sammenhænge mellem hhx-elevernes habitus og livsstil eller orientering i det sociale rum og deres praksis såvel $i$ klasseværelset som i livet i øvrigt." (s. 11). Alligevel giver bogens godt 200 sider stort set ingen data om de nævnte sammenhænge. Endnu mindre om alt det, som også den medfølgende "pressemeddelelse" (Nyt fra Danmarks Pædagogiske Institut, nr. 220) lover, eksempelvis når man der fremhæver, at bogen lægger "vægt på at beskrive de sociale forskelle inden for hhx og derigennem indkredse den sociale differentiering, der foregår undervejs i uddannelsen." Efter denne anmelders opfattelse er der tale om vildledende markedsføring. UB er dog selv opmærksom på, at værket ikke lever op til forventningerne om væsentlig ny viden om hhx-elever. Bogens problemstilling bliver da også undervejs - med forfatterens karakteristiske sprog- brug - omformuleret til "... hvordan man konstruerer hhx-elever som forskningsobjekt." (s.137). UB tager her afsæt i en kritik af tre andre uddannelsesundersøgelser, nemlig en fra Amternes og Kommunernes Forskningsinstitut, en fra Danmarks Erhvervspædagogiske Læreruddannelse og en undersøgelse, som denne anmelder har gennemført. Disse undersøgelser beskyldes for mangel på teoretisk grundlag eller for den sidstes vedkommende kun at antyde et sådant grundlag. For at sætte ekstra trumf på består det korte kapitel 3 af et ukritisk referat af en artikel af psykologen Sven Mørch i Unge pædagoger, nr. 6, 1995. Den pågældende artikel bruger denne anmelders bog $E n$ generation blev voksen (1995) som eksempel på en forskningstradition, der i UBs referat tolker statistiske sammenhænge "som indholdsmæssige sammenhænge" og endda som nærmest kausale" " og derudover "forfejler forståelsen af hele spørgsmålet" på grund af begrebet social arv, der peger på en "nedarvet skæbne indlejret i den enkelte."(s.4748). Ironisk nok er det lige præcis, hvad min bog ikke gør.

Kritikken er således helt malplaceret og fremdrages da også kun, fordi den spiller en afgørende rolle for UB, når han i sin bogs centrale dele vil forklare læseren, hvordan man bør forske. Han mener, at Bourdieus begreber er det centrale redskab og bruger derfor sit ka- pitel 4 til en gennemgang af disse - $\mathrm{i}$ hvert fald for sociologer velkendte - begreber. Med denne ballast går UB i gang med sit kapitel 5 med titlen: "Begyndende etablering af hhx-elever som genstand for forskning." Kapitlet er "helliget en refleksion af forholdet mellem teori og empiri"(s. 81). Han får her slået fast, at virkeligheden er relationel og at forskning, der vil være empirisk forankret også må være teoretisk forankret.

Efter denne eksercits i velkendte banaliteter følger kapitlerne 6 og 7. Her er UB tilsyneladende på hjemmebane. I hvert fald kan disse kapitler varmt anbefales. Kapitel 6 handler om højere handelseksamens etablering diskuteret i relation til den politiske og økonomiske udvikling i Danmark fra midten af 1600-tallet. Her konkluderes, at den hhx vi kender i dag er båret frem af handelsborgerskabets interessekamp på trods af stor modvilje i det øvrige uddannelsessystem. Perspektivet var dels en større mængde af kundskaber og færdigheder til netop denne sektor, dels en fremvoksende gruppes symbolske kamp om status og anseelse.

Kapitel 7 med titlen: "Hhx i spændingsfeltet: Dannelsehalvdannelse" er en spændende gennemgang af diskussionerne - ikke mindst i 1800-tallet - af dannelsesbegrebet. Diskussioner, der kan sammenfattes i de postulerede(?) modsætninger mellem almen dannelse og faglig dannelse. Samtidig på- 
peges det, at dannelsesproblematikken er en del af den historie, som uddannelsesinstitutioner bærer med sig. UB sammenholder dannelsesbegrebet med Bourdieus livsstilsbegreb. Begge begreber fokuserer på forskellige gruppers værdimæssige hierarkier og normative orientering, der kan fungere som kapital til opnåelse af højere positioner i det sociale rum.

Efter disse kapitler kommer antiklimaks, nemlig den af UB gennemførte ikke repræsentative spørgeskemaundersøgelse blandt hhx-elever på en Niels Brock afdeling i København, på Århus Handelsskole og på Lyngby Uddannelsescenter. Nu skulle man tro, at UBs tanker om en teoretisk forankring i Bourdieus forskning havde ført til en konkret diskussion af og en argumention for operationalisering af netop Bourdieus begrebsverden. Dette er dog ingenlunde tilfældet. UB indsamler nemlig data til variabler af fuldstændig samme art og operationaliseret efter de samme principper som i de af ham kritiserede undersøgelser. Blot med den forskel, at variablerne i de kritiserede undersøgelser ofte er såvel bedre teoretisk funderede som bedre operationaliserede.

Enkelte citater fra hans omtale af sin undersøgelses resultater kan illustrere deres analytiske fattigdom. Det viser sig $\mathrm{fx}$, at $71 \%$ af eleverne erklærer sig helt eller delvist enige $i$, at de har en kæreste to år senere (s.190), og når UB dernæst kaster sig over en primitiv beskrivelse af den gennemsnitlige(!) hhxelev kan han fortælle, at "eleven er fælleskøn, har gået 10 år i folkeskolen, har ikke været på efterskole, og har sluttet folkeskolen med udvidede prøver i Dansk, Matematik og Engelsk ..." og sådan fortsætter det bare derudad (s.194). Herefter opdeler han respondenterne efter faderens uddannelse (et social klasse begreb opererer han overraskende nok ikke med - hverken i Bourdieus forstand eller med en anden teoretisk forankring) og han når bl.a. frem til, at elever, der har en far uddannet på "Kontor", ser "i højere grad nyheder i tv og musicals og erotiske film i biografen" (s. 199), mens børn af "mellemuddannede" fædre i højere grad "ser krigsfilm, når de går i biografen." (s. 199). UB erkender selv, at materialet er atomiseret, og at han selv har vanskeligheder med at få et samlet overblik, men hvor er Bourdieu henne i alt dette?

Jo, på den næstsidste side nævner UB bl.a., at "materialet indikerer en sammenhæng mellem mængden af kulturel kapital, målt ved faderens uddannelsesniveau, og mængden af økonomisk kapital, antydet ved graden af parcelhus." (s. 201).

Man må derfor spørge, om Bourdieus teori blot skal bruges til at klistre andre etiketter på præcis de variabler, som andre forskningstraditioner også anvender?

I hvert fald er UBs værk en bog, der skriger efter en faglig referent, som kunne have peget på, hvordan manuskriptet kunne været skåret ned til en læseværdig bog på højest 50 sider.

\section{Erik Jørgen Hansen}

Danmarks Pædagogiske

Universitet

\section{Peter Maskell \& Gunnar Törnqvist: Building a Cross-Border Learning Region. København: Handelshøjskolens Forlag, 1999 (85 s.)}

Ordet "læring" optræder i stadig nye sammenhænge og sammensætninger inden for samfundsvidenskaberne. Det er til en vis grad et modefænomen; men det er også udtryk for en øget forståelse af, at læreprocesser på mange niveauer er en central og dynamisk faktor i samfundsudviklingen. Begrebet "lærende region", som behandles i denne lille bog, er et godt eksempel på dette. Hvor teorier om regional udvikling ofte har fokuseret på betydningen af naturressourcer og infrastruktur, peger begrebet "lærende region" på, at viden og erfaring kan være mindst lige så væsentlige ressourcer for regioners udvikling.

Paradoksalt nok er bogen skrevet $i$ anledning af et stort infrastrukturprojekt, nemlig Øresundsbroen. OECD har gennem de sidste par år afholdt en serie konferencer om lærende regioner, og én af dem blev holdt i København i 1999 med fokus på 
Øresundsområdet som en tværnational lærende region. Maskell og Törnqvists bog er skrevet som baggrundsmateriale til denne konference. Hovedformålet er ifølge forfatterne at undersøge regionale sammenhænge mellem læring og konkurrenceevne. Men Øresundsområdet er en særlig slags region, og derfor kommer bogen også til at handle om forholdet mellem regioner og nationalstater.

Den regionale udvikling i Europa efter murens fald er hovedtemaet i første del af bogen. Det nye Europakort er kendetegnet af en ustabil mangfoldighed, og kan minde om tilstande, der tidligere i historien har optrådt efter sammenbruddet af stærke regimer som f.eks. det Habsburgske. Alligevel er der visse gennemgående tendenser i udviklingen. Økonomier bliver stadig mere afhængige af hinanden, og de nationale grænser får stadig mindre betydning for økonomiske og kulturelle forbindelser. Nationalstatens magt undermineres. I denne proces får regionerne øget betydning, som mindre enheder der kan udtrykke særlige identiteter. Virksomheder udvikler egne netværk på tværs af landegrænser, og ofte i global målestok. Også inden for højere uddannelse, forskning og kunst udvikles der globale netværk. Netværkene kanaliserer kapital og viden, og rammerne for megen af den innovation, der foregår i dag. Forfatterne tilslutter sig således Castells begreb om netværkssamfundet.

Tendensen til regionalise- ring tager ifølge forfatterne tre forskellige former. Den første svarer til decentralisering, en bevidst overflytning af magt og beslutningskompetence fra det nationale center til det regionale niveau. Den anden form er udfoldelsen af regionale kulturelle traditioner, som er dybt forankret i den europæiske historie. Dette indebærer ofte konflikter med centrale myndigheder og tendenser til separatisme. Den tredje form forekommer, "..hvor lokale og regionale kræfter bevidst stræber efter at skabe en region, som endnu ikke eksisterer, eller mere præcist formuleret prøver at styrke en allerede eksisterende, men underudviklet regionalisme i et område" (s. 18). Øresundsregionen må formodes at høre til den tredje type. Det rejser imidlertid spørgsmålet, om kræfterne bag denne endnu ikke eksisterende region kan forstås som lokale og regionale kræfter. Det diskuterer forfatterne ikke.

Der er i Europa mange eksempler på sammenhængende regioner, der går på tværs af nationale grænser. En del af disse regioner har dybe historiske rødder, men er blevet opdelt i forbindelse med dannelsen af nationalstater. Men der skabes også nye tværnationale regioner. Siden 1989 er der i Centraleuropa blevet skabt en række samarbejdsaftaler mellem regioner, der ligger på hver sin side af grænserne mellem nationalstater, herunder også det tidligere jerntæppe. Maskell og Törnqvist hævder, at denne form for samarbejde er i stærk vækst, men deres noget impressionistiske fremstilling dokumenterer ikke dette. Der er mange eksempler, men ikke så meget kritisk vurdering af samarbejdernes rækkevidde og betydning.

Der er forskellige motiver for udviklingen af samarbejde inden for tværnationale regioner. Fra starten spillede sikkerhedspolitiske hensyn en stor rolle. Samarbejdet skulle forebygge politiske konflikter. I dag er samarbejderne snarere led i en generel integrationsproces på europæisk plan. De økonomiske motiver er blevet mere fremtrædende. Samarbejdet skal skabe væksbetingelser ved at udvide de lokale markeder og tillade en mere effektiv brug af arbejde og kapital. De tværnationale regioner udgør en slags "gråzone" mellem det private og det offentlige, en gråzone hvor firmaer, universiteter, handelskamre, fagforeninger, politiske partier og kulturelle organisationer er nogle af de vigtigste aktører. Samarbejdet sker ofte via paraplyorganisationer baseret på netværk.

I anden del af bogen udfoldes begrebet lærende region. Den igangværende globaliseringsproces bliver politisk og økonomisk drevet af ønsket om at opnå de økonomiske fordele ved en øget arbejdsdeling mellem firmaer og regioner, når grænserne mellem nationer bliver mere gennemtrængelige. Dette er en udfordring for gamle regioner, hvor lønomkostningerne er høje. Mange forventer, at globali- 
seringen vil skærpe konkurrencen fra udviklingslande med lave lønninger, hvilket vil føre til stagnation og øget ulighed i de gamle industrilandes regioner. Virksomheder i disse regioner kan vælge forskellige strategier over for denne udfordring. Én mulighed er at investere i teknologi og dermed reducere lønniveauets betydning. Det har imidlertid ofte den ulempe, at virksomhederne får sværere ved at omstille sig til ændringer i efterspørgslen. En alternativ strategi, som stadig flere virksomheder bruger, er forbedre kapaciteten til læring og omstilling, og dermed blive bedre til at udnytte efterspørgsel og innovationsmuligheder. Vigtige elementer i dannelsen af lærende regioner er kritiske og vidende kunder, kompetente leverandører, tillidsfulde relationer og netværk mellem virksomheder og en høj grad af konkurrence inden for erhvervslivet. Vigtigt er også eksistensen af et regionalt "modtagersystem", som kan støtte firmaerne i at finde og vælge internationale teknologiske innovationer.

Begrebet lærende region gør det naturligt at fokusere på forsknings- og uddannelsesinstitutioners rolle, og det gør Maskell og Törnqvist da også. De advarer mod at tro, at højere uddannelse automatisk er en drivkraft i regional økonomisk udvikling. Empiriske undersøgelser peger på, at hvor der i nogle regioner opstår synergi og innovative miljøer omkring højere uddannelsesinstitutioner, kan virksomheder og universiteter $\mathrm{i}$ andre regioner eksistere side om siden, uden at der udvikles væsentlige forbindelser imellem dem. I den forbindelse giver forfatterne en væsentlig præcisering af begrebet kritisk masse, der ofte ses som en forudsætning for synergi. Kritisk masse er ikke blot et spørgsmål om størrelse eller koncentrationsgrad; det handler om kommunikationstæthed snarere end om antallet af personer, som deltager i kommunikationen. Den høje grad af social integration i lidt mindre sociale enheder kan være et grundlag for vækst og innovation, mens større sociale enheder rummer risiko for blokeringer.

På denne historiske og teoretiske baggrund giver forfatterne så en kortfattet analyse af Øresundsregionens særpræg og udviklingsmuligheder. De understreger, at hverken den danske eller den svenske del af regionen er præget af højteknologi. Det er der gode grunde til. Omkostningsniveauet ved højteknologi er højt, hvilket kræver et stort marked. Små lande, som investerer i udvikling af højteknologi, vil ofte se de store lande udnytte resultaterne, fordi de har de mest alsidige ressourcer til det. Men lande som Danmark og Sverige ser ud til at kunne opretholde en høj velstand via en ikke-højteknologisk udviklingsvej.

På trods af Københavns tilstedeværelse må den industrielle struktur i Øresundsområdet således beskrives som overvejende lavteknologisk: De forsknings- og udviklingstunge virksomheder samt de vidensintensive erhverv udgør kun en lille del af erhvervslivet. Både i den svenske og den danske del af området er der relativt mange universitetsuddannede, men de fleste af dem arbejder i administration, undervisning eller forskning. Det ikke er tilstedeværelsen af universitetsuddannede i industrien, som kendetegner regionen. Kompetence og læring handler imidlertid om andet end højtuddannet arbejdskraft, ikke mindst om uformel læring i tilknytning til arbejdet. På grundlag af indirekte indikatorer (bl.a. arbejdskraftens bevægelser) konkluderer forfatterne, at den konkurrenceevne, som findes i virksomhederne i Øresundsregionen, primært bygger på "learning by doing" og på interaktion mellem ligestillede parter i erhvervslivet. Øresundsregionen hører til den type lærende regioner, hvor forbindelsen mellem universiteter og iværksætteraktiviteter er svag.

På grundlag af Maskell og Törnqvists analyse skal man således ikke forvente, at Øresundsområdet bliver en europæisk Silicon Valley. Den danske og den svenske undervisningsminister, som i deres fælles forord skriver, at "denne region har potentiale til at blive et af de stærkeste centre for viden i Europa" (s. 5), burde have læst bogen grundigere. I konklusionen peger forfatterne på, at Øresundsregionen som økonomisk enhed kan risikere at få samme skæbne som nogle af de store fusioner i erhvervslivet: Synergien bliver større 
end ventet, men negativ. Forventninger om store og hurtige gevinster vil blive skuffede. Der kan opstå nye sociale problemer, når parallelle offentlige og private servicefunktioner, der er opbygget på hver side af sundet, udsættes for rationaliseringspres. Den centrale udfordring ligger $i$ at forøge konkurrenceevnen for de virksomheder i regionen, som konkurrerer og arbejder internationalt. Her er de offentlige myndigheders indsats på forskellige niveauer afgørende; der er brug for en "omhyggeligt orkestreret og socialt afbalanceret fornyelse af de formelle og institutionelle rammer i regionen" (s. 79), for at gevinsterne vil være større end omkostningerne ved at skabe nye alliancer og net- værk. Men det er en lang proces at skabe politisk-administrative organer, som kan fungere målrettet på regionalt, tværnationalt plan.

Som det nok fremgår, er det komplekse sammenhænge, Maskell og Törnqvist behandler i deres lille bog. Fremstillingen er på mange måder velargumenteret, men kunne have været disponeret mere klart og logisk. På et par områder savner jeg mere dybde og konsekvens $i$ analysen. Det gælder for det første årsagerne til, at udviklingen af Øresundsregionen er blevet et så væsentligt politisk projekt. Der er naturligvis økonomiske drivkræfter på et generelt plan, men på det mere konkrete plan er de ikke så indlysende, viser analysen. Det er næppe heller en stærk kulturel samhørighed, der bærer projektet. Men hvad er det så? Det diskuterer forfatterne ikke, og dermed kommer de i nogle afsnit til at fremstille projektet som en naturlig, uafvendelig udvikling. For det andet synes jeg analysen af den uformelle læring er for overfladisk. Det er paradoksalt, at bogens empiriske stof om uddannelsesforhold stort set kun handler om universiteter og universitetskandidater, når nu forfatterne finder den uformelle læring mere væsentlig for konkurrenceevnen. De bruger f.eks. slet ikke den eksisterende viden om virksomhedernes anvendelse af arbejdsmarkeds- og efteruddannelse.

Palle Rasmussen

Videnscenter for Læreprocesser, Aalborg Universitet 